\title{
Functional and spatial changes of souks in Morocco's imperial cities in the context of tourism development
}

\begin{abstract}
Souks have undergone functional and spatial changes in the Moroccan medinas since colonial times due to the tourist activities. The rate of the changes increased at the end of the 20th century because of the expansion of tourism projects. However, there are no publications on the evolution of Moroccan souks in the context of tourism development. Therefore, the purpose of this article is to determine the types of transformations the souks underwent as a result of the dynamic development in this sector of economy. The research focused on two imperial cities: Marrakech and Rabat. Data for analysis was obtained through observations and field interviews in 2014 and by bibliographic query. A retrospective study was carried out which included identification of mechanisms affecting the contemporary organization and physiognomy of the commercial streets. The authors' work allowed for an identification of development phases of the Moroccan souks under the influence of tourism.
\end{abstract}

Keywords

Tourism impact - souk transformation - spatial dynamics - functional dynamics - Moroccan medina • Morocco's imperial city

(C) University of Warsaw - Faculty of Geography and Regional Studies

\author{
Karolina Kania ${ }^{1}$, Maciej Kałaska ${ }^{2}$ \\ 'PSL Research University, EHESS-CEMS, \\ France \\ e-mail: karolina.kania@ehess.fr \\ ${ }^{2}$ Faculty of Geography and Regional Studies, \\ University of Warsaw, Warsaw, Poland \\ e-mail: m.kalaska@uw.edu.pl \\ Received: 27 June 2018 \\ Accepted: 20 December 2018
}

Introduction

The Moroccan souk (bazaar), located in the narrow streets of a medina, is an inseparable element of the medina's structure. It is an important place in which trade, craft, and public life flourish. With the development of tourism, mostly during the post-colonial era ${ }^{1}$ the medinas in Moroccan cities - and especially the souks located within them - became an attraction for foreign tourists. The development of this sector of the economy caused a collapse in some crafts in favour of trade, leading to changes in spatial and functional organization. These changes have made it difficult to maintain the traditional activities and functions of the souks, because adapting to the needs and expectations of tourists has become a priority.

Tourism is not the only factor which determines the transformation process affecting the souks. In colonial times the French decided that some medinas, as well as their souks, would serve as vital symbols of the primitivism of Islamic precolonial culture (Escher \& Schepers 2008). This decision resulted in them being converted into open-air museums. Other medinas were changed so that they met the requirements of the modern economy (Theliol 2014). During the first decades of Morocco's independence (1956 to the 1980s) demographic pressure and an improved quality of life for rural communities living in the vicinity of Moroccan cities resulted in the spatial expansion of the souks (Lagdim Soussi 1982). Also, from the late 1980s onwards, the tendency to copy Western

${ }^{1}$ The first economic development strategy, which was implemented during the years 1960-1964, had already defined tourism as a priority for the country's development (Cauvin Verner 2005, Daoudi 1994). This sector still occupies an important position in the Moroccan economy: according to the Ministry of Tourism of the Kingdom of Morocco, more than 10.3 million tourists visited the country in 2016 . lifestyle - which can be observed in Islamic society, and not only in Morocco - led to secularization and has had a great impact on the functioning and appearance of the medinas' bazaars (Łęcka 2017). However, this article focuses only on the tourism aspect while keeping in mind the local and global social, cultural, and political factors operating in souk dynamics.

The purpose of this article is to identify the types of transformations that souks have undergone in Morocco's imperial cities in the context of tourism development. This will allow the identification of the development phases of the Moroccan souks that have been influenced by tourism.

Scientific papers devoted to the commercial streets of Moroccan medinas discuss their spatial organization (Troin 1975), however, the increasing impact of tourism on souks is also being taken into account. The issues of creating tourist products or building relations between tourists and indigenous people have been discussed in the literature (Cauvin-Verner 2006, Leroux 2008). However, this research topic is rarely undertaken from a historical perspective (Widmer-Münch 1990). The processes affecting the changes in character of the medinas' shopping streets are complex and deserve in-depth analysis.

\section{Research methodology}

Study area

The research work focused on two cities: Marrakech and Rabat, both of which were founded in the Middle Ages. They belong to the group of 'imperial cities of Morocco' along with Fez and Meknes. The medinas, which are distinguished in the morphological structure of today's cities, date back to this period, 
(there are a total of 31 of these medinas in Morocco). In the central part of the medinas can be found the souks.

The choice of Marrakesh and Rabat was not accidental. The research team looked for a pair of cities from among the four imperial cities which differed most in terms of the tourism role of the souks, and the economy as a whole. Resulting from this, the types of souk transformations that have taken place under the influence of tourism, as identified during the research, could be extrapolated to other imperial cities. It was assumed that if a group of similarities could be found between the two most diverse cities, then the same similarities were likely to occur in the other cities. The importance of souks as a tourist attraction has always been much smaller in Rabat than in Marrakech. This differentiation results from the fact that the cities held the status of capital in completely different periods. Marrakech served as the administrative centre as early as the eleventh century, and continued as such, with interruptions, for many centuries; while Rabat has been the capital only since 1912, when the French protectorate was created in Morocco. Therefore, a trading tradition was formed much earlier in Marrakesh than in Rabat. These cities differ also in terms of the intensity of their tourist traffic, ${ }^{2}$ however, in the opinion of the authors of this article, the souks in these cities have been subject to similar processes in relation to tourism.

\section{Research materials and methods}

Part of the data was obtained during field research undertaken in 2014. Overt, covert, and participatory observations were carried out, as well as in-depth, semi-structured interviews. Ten interviews were conducted with traders and craftsmen; while ten were undertaken with foreign tourists in each of the cities of Rabat and Marrakesh. In total, forty interviews were subjected to analysis. The tradesmen and craftsmen came from families with generations of trading traditions. All the tourists were French - this is the most numerous group of foreigners to visit the two cities being analysed, and has been so since colonial times. The selection of the subjects participating in the study was based strictly on the specific research topic. In order to achieve the goals, it was necessary to adopt a comparative perspective and avoid generalization for the phenomena described (Srinivas, Shah \& Ramaswamy 1979).

During the interviews, the subjects were asked pre-prepared questions in an order that was suitable for keeping the natural flow of the conversation going. Interviews carried out with a number of informants allowed the received information to be juxtaposed and compared in order to ensure the independence one of the source of information (de Sardan 1995). Sometimes, taking notes and voice recording seemed to embarrass the interviewees, who were then more careful in sharing information and weighed their words. Nevertheless, the voice recorder proved to be an important tool in helping with further work on the data collected.

Using the information obtained from the field studies, as well as on the basis of the literature available, the impact of tourism on the functioning of the shopping streets in the medinas in 2014 is presented in a section of this article entitled 'The souks of Morocco's imperial cities in 2014.' In the next part of this article - 'The types of transformations undergone by the souks through the influence of tourism' - a retrospective analysis of the souks' functioning was carried out in the context of tourism development since colonial times. This was made on the basis of literature on the subject, however scarce, and complemented by information obtained during the interviews. It was carried out in such a way as to define the tourism-related mechanisms which influenced

${ }^{2}$ In 2016, Marrakech was visited by more tourists than any other city in Morocco (1.8 million). Rabat (the capital city of Morocco), on the other hand, is a place for short stops, not a final destination (in 2016, only 400,000 tourists visited the capital of Morocco). souk development up until 2014. This allowed the authors to distinguish the development phases in the growth of tourism. The emergence of subsequent phases was due to the appearance of a new type of transformation.

\section{The souks of Morocco's imperial cities in 2014}

The souk is a place of trade, meetings, discussion, and transactions. The market plays an important role in local community life (Awad 1989). Today, a large number of marketplaces operate every day, becoming places for cultural and social events in addition to being trade centres (Łęcka 2017). In the medinas of Moroccan cities, souks satisfy essential urban functions and are located in old, narrow streets among cramped buildings (Troin 1975), where, on the ground floor of many houses, there are workshops and shops facing the street. The shops offer products manufactured in workshops located at the back of the houses. The production and trade zones are located near the city's main mosque, which is at the centre of the medina, and is structured in such a way as to observe the separation of the clean from the unclean, creating concentric zones around the population centre's main mosque. In its vicinity, perfumes and incense are located because, according to an interpretation of the Quran, they are considered sacred; while farthest away are the workshops for the unclean professions, for example, dyers and paint mixers (Dettmann 1969).

The rich history of Morocco has left an abundance of cultural wealth (Jędrusik 2010). Currently, souks are one of Morocco's biggest tourist attractions. Visiting the marketplace to purchase souvenirs is an inseparable part of any trip and is considered standard tourist behaviour - it is one of many tourist rituals. Tourists not only shop there, but also interact with representatives of the local community by conversing or negotiating prices. In Morocco, chtara, or bargaining, is a tradition and an integral part of shopping - tourists have to take part in this practice. This is how a tourist described the bargaining at a souk in Rabat: 'The seller says the price, I negotiate, I leave, he calls me, I come back, we negotiate, I leave and so on. If I have a lot of time, I can continue doing this for a while.' ${ }^{3}$ Houcine, a bag salesman from Rabat, said that, 'tourists are very good at bargaining. ${ }^{1}$ According to the tradesmen, the fact that the prices are not fixed in advance allows you to keep up with the competition. The interviewees often emphasized the difference between bargaining in the souks of Fez or Marrakesh, and bargaining in Rabat's souk. As the sellers in Rabat feel less touristic pressure than they do in other Moroccan cities, the prices they set are more reasonable. In more touristy cities, sellers set high prices and are more aggressive in their bargaining with customers. Often, it is the guides who increase the prices (the commission they charge is up to half the price of a given product). This is why sellers from Rabat, when describing the souks in Marrakech, said that 'Marrakech c'est l'arnaquech' (Marrakesh is a scam). 'In Marrakesh, false guides increase prices. In Rabat, the price will never be doubled, and sellers do not cooperate with guides,' said a salesman from Rabat who sells argan oil at fixed prices which are posted in the store. ${ }^{5}$ Souks served as places for open interaction between tourists and locals in colonial times, as they do today. Nevertheless, the relationships established between local guides, sellers, and foreign tourists are limited to economic aspects and lead to the commercialization of contact (Bouzidi 1996).

${ }^{3} \mathrm{An}$ interview with a French tourist who came to Rabat with his wife and daughter; his family comes from Morocco. They stayed a week. Place of interview: rue des Consuls; date of interview: 16.04.2014.

${ }^{4} \mathrm{An}$ interview with Houcine a bag merchant. The interview was conducted in his shop at 233, rue des Consuls, Rabat. Date of interview: 14.04.2014.

${ }^{5} \mathrm{An}$ interview with an argan oil merchant. The interview was conducted in his shop at 196, rue des Consuls, Rabat. Date of interview: 19.04.2014. 

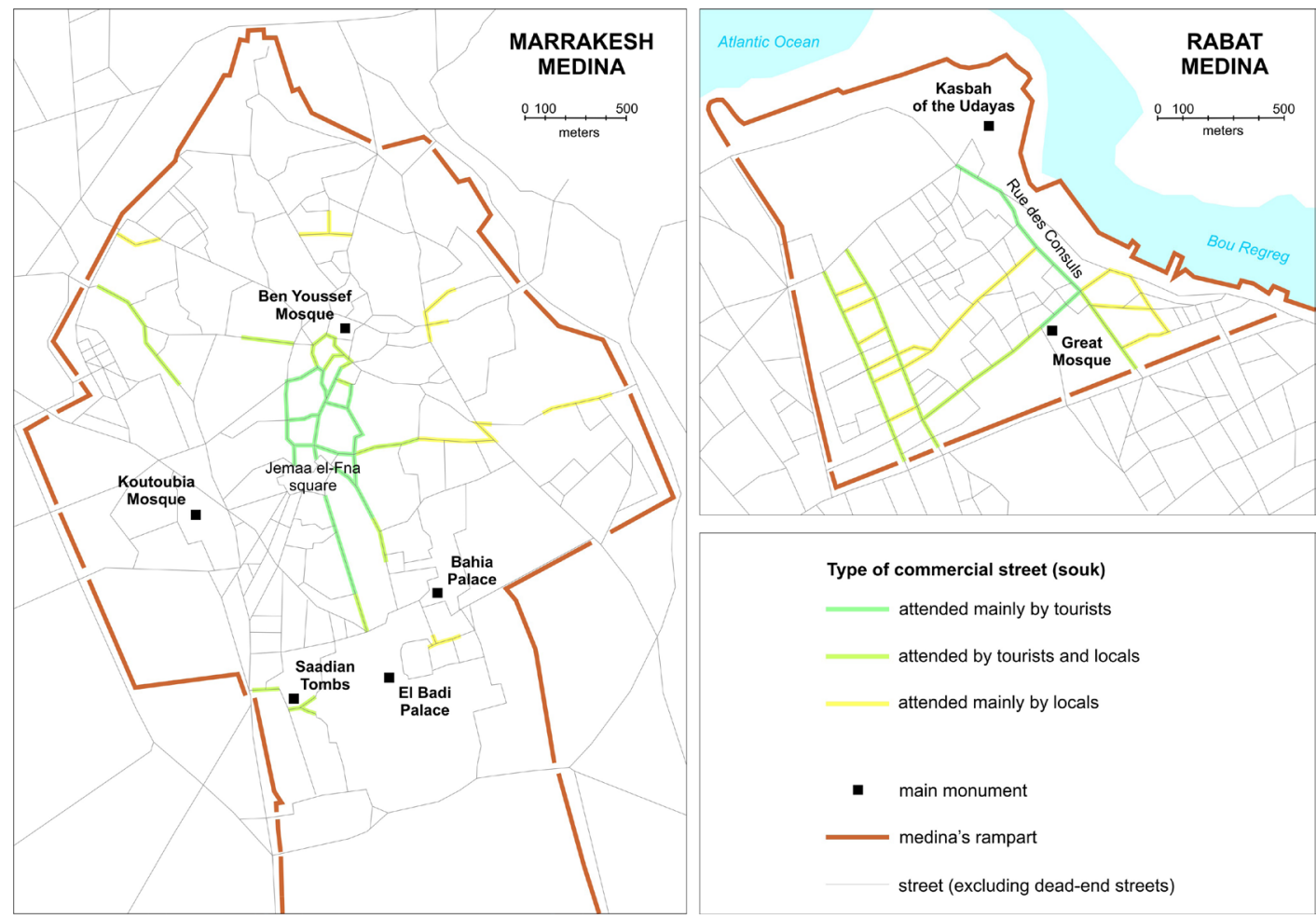

Figure 1. Commercial streets in the Marrakesh and Rabat medinas in 2014 Source: own elaboration on the basis of fieldworks undertaken in 2014

The souks of Rabat and Marrakech's medinas share many common features. One of these is the division of commercial streets. In 2014, on the basis of observations and interviews, three characteristic parts of the souks were distinguished (Figure 1). The first part is used mainly by tourists (Figure 2). It is located in the vicinity of the most visited monuments, or on the routes connecting them; and is characterized by an assortment of establishments targeted at wealthy clients, usually from abroad. Workshops and shops filled with traditional handicrafts are adjacent to boutiques where objects inspired by classic Moroccan design can be found. The items on offer reflect the expectations of Western clients who look for unique and designer products. However, the number of these types of shops is much lower in Rabat than in Marrakech. In the second part of the souks, the shoppers are mixed, but it appears that there are more local customers in these areas. The third part is located in the depths of the medina, away from the main tourist attractions, and is dominated by the local community, usually by people who live in the medina (Figure 3). In the second and the third parts, which are the daily shopping places for members of the local community, there are primarily shops and stalls selling everyday items such as food products, bags, cosmetics, shoes, and clothing (often counterfeit). In the alleys that adjoin the main streets of the medina there are small pottery, carpentry, tailoring workshops, mangles (cloth presses), as well as hairdressers, internet cafes, and restaurants. It was also observed that the parts of the souks visited by tourists and the parts dominated by locals differ from each other. The former are distinguished by decorated fountains and house facades.

The types of transformation undergone by the souks through the influence of tourism

Within the first years of the French Protectorate (1912-1956) a decision was made to protect the architectural heritage of the

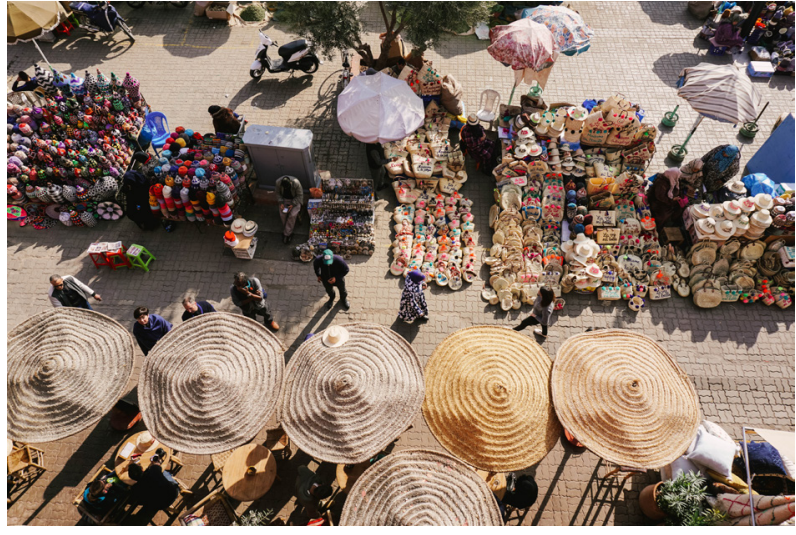

Figure 2. The Souk in Rahba Kedima Square - a tourist part of the medina in Marrakesh (photo: K. Kania)

Marrakech and Rabat medinas (Escher \& Petermann 2014, Minca \& Borghi 2009). The classification and protection of monuments was carried out and aimed at preserving the aesthetic appearance of the parts of the city which were appreciated by European tourists. As tourism was an important part of the urban economy, the Department of Antiquities, Fine Arts and Historical Monuments rigorously applied all town planning regulations in the medina, and did not allow any violations (Théliol 2014). During the interwar period, the colonial authorities became interested in cultural heritage as a driving force for tourism development. Many activities in the medinas were focused on creating openair museums. Many activities in the medinas were focused on creating open-air museums, and thus they created a museum which presented the products of the Arab civilization (Leroux 2008). 


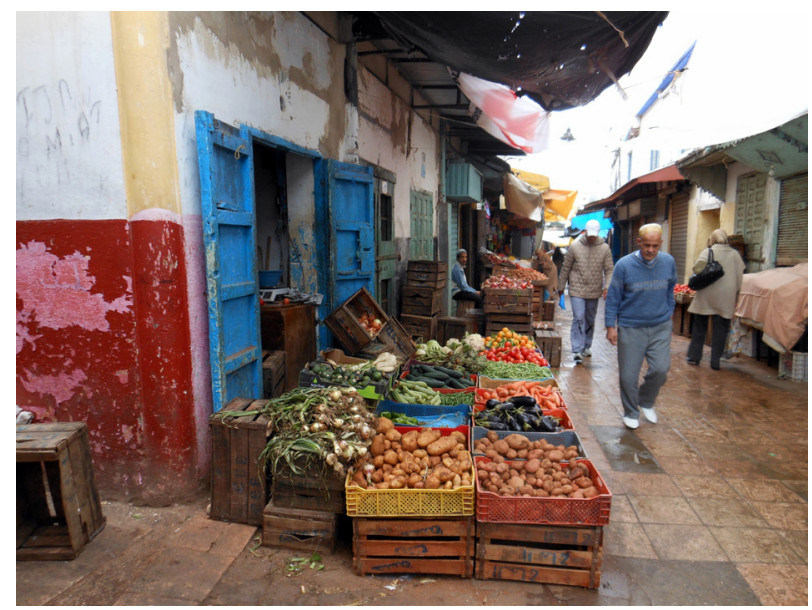

Figure 3. The food market on Bouqroune Street in the medina of Rabat (photo: K. Kania)

Following the example of Tunisia, the souks were treated as a valuable whole - holding artistic value to be promoted for tourism (Bacha 2008). They have become tourist attractions as a result of the process of sight sacralisation ${ }^{6}$ (MacCannell 2013).

In the times of the protectorate, most marketplaces focused mainly on local and regional clients, not tourists (Widmer-Münch 1990). The assortment of goods was always the same and included day-to-day products for the locals. From year to year, the number of tourists visiting Moroccan cities increased, but it did not exceed 50,000 people per year (ed. Hoffherr 1936). The tourists found the surroundings of the souks disturbing - in their eyes they were too dirty and chaotic.

In the first decades of Moroccan independence (1956), the authorities sought to maintain the rules for the conservation and protection of monuments which had been established during the protectorate. The relationship between the development of tourism and the shaping of cultural heritage, however, was not as pronounced as in colonial times. The issue of preserving the authenticity and integrity of the souks in the medinas was omitted from urban policy. From 1965, that is, with the beginning of the implementation of tourism policy goals, many bazaars were built in the medina of Marrakech. In 1985, there were already 165 such facilities established (compared to only 35 at the beginning). They were usually located north of the Jemaa el-Fna square, close to the pre-colonial souks. One of the reasons for choosing this location was the desire to use the existing facilities. The most important factor, however, was tourist traffic, which grew as a result of the promotion of mass tourism in development strategy documents (Stafford 1996). New commercial facilities were created at the expense of residential houses and were located on routes connecting the most visited architectural monuments (Widmer-Münch 1990). The narrow streets leading to the souks were also occupied by small shops offering products to tourists, and marketplaces spread to neighbouring areas (Leroux, 2008). In addition, most of the production happening in souks stopped over time as a result of the liquidation of traditional workshops (Bouzidi 1996). From the beginning of Moroccan independence souks were subject to a process of bazardisation, otherwise known

${ }^{6}$ Objects become tourist attractions via a complex social process - sight sacralisation. This consists of five phases (MacCannell 2013). In the first phase - naming - souks in the medinas are separated from the wider background as especially attractive for tourists. Their significance for tourism and culture is recognized, among other things, in planning documents. In the second phase - framing and elevation - the souks are distinguished by their partial ordering and signposting. In subsequent stages, they are mass-replicated thanks to guides and other forms of tourism promotion. as tertiarisation. ${ }^{7}$ This process forced craftsmen to relocate their small workshops from the centres of the medinas to the peripheral and neglected districts (Kurzac-Souali 2007a, Lagdim Soussi 1982), thus increasing the souks' spatial dispersion.

In Rabat, as in Marrakesh, the development of tourism has led to a number of changes. The biggest changes took place at the turn of the twentieth and twenty-first centuries when the trade profile of the souks underwent major changes as a result of the development of the tourism industry (Ernst 2013). In 2014, the sellers and residents of the Rabat medina mentioned that back in the 1990s Moroccan handicrafts were sold in the souks, but at the time most of the products sold there were made in Asia. 'In the years 1990-1995 there was a radical change in trade. Instead of traditional Moroccan crafts we started selling modern items.' ${ }^{8}$ Since then, tourists have also changed their shopping habits. A tourist who has been regularly visiting Morocco for the last 40 years remarked, 'In the past, we would put our souvenirs in a display case, today the approach is changing: on the one hand, the souvenir reminds us of the country we visited, on the other hand we want the items purchased to be useful in the kitchen or in the bathroom. Craftsmen and salesmen adapt to the tourists, and items more and more often have nothing to do with the Moroccan style. ' ${ }^{9}$ As observed by tradesmen during the interviews, tourists buy less and prefer cheaper products of lower quality, while fakes are very popular - this is the process of bastardisation of craft products (Lagdim Soussi 2002). The traditional trades and crafts have adapted to the needs of tourists.

The inclusion of parts of Marrakesh (in 1985) and Rabat (in 2012) in the UNESCO World Heritage List gave the authorities new opportunities to develop tourist activities. This classification included the medinas of both cities and the areas occupied by the souks. A. Escher and M. Schepers (2008: 130) note that the renewal processes in the old towns of Morocco 'are usually part of global contexts; the predominantly tourism-oriented use ensures the preservation of buildings and structures and contributes to transforming the given infrastructure and character of the old towns.' The authorities, in cooperation with international organizations such as the World Bank or UNESCO, gradually began to renew the trade and craft occupied areas in the medinas. (Carson, Mitchell \& Conaway 2002). These works have accelerated with the implementation of social (e.g. Initiative Nationale du Développement Humain) and tourism programs (Vision 2010, Vision 2020), along with the succession of Mohammed VI, King Hassan II's son, in 1999 (Nachouane 2015, Minca \& Borghi 2009). The new monarch, maintaining stable power after his father, changed the tourism policy concerning the souks. Fighting against the bazardisation of the trading areas in the medina, which was the result of the development of mass tourism, he initiated efforts to increase their touristic attractiveness. For this purpose he created special funds which permitted the ordering of the souks and an improvement in the working conditions within them (Godin \& Le Bihan 2012).

These changes were also related to the improvement of security in the crowded parts of the medieval old town (securitisation of space). In Marrakesh, a tourist police force

'Bazardisation is the process of the gradual loss of the souks' dual function. In old locations, craftsmen's workshops have been displaced by tradesmen's stalls. The disproportion between the number of workshops and tradesmen's stalls has been growing as newly established businesses are all sales points. The reason for this change is in the development of tourism. As a result, the double function of the souks, i.e., manufacturing and services, has gradually given way to services only (Lagdim Soussi 1982).

${ }^{8}$ An interview with a shoe merchant, conducted in his shop. Place of interview: 287 Souika Street, Rabat; date of interview: 21.04.2014.

${ }^{9} \mathrm{An}$ interview with a French tourist (Madeleine), who buys presents in the Rabat souk for her family and friends in France. Place of interview: rue des Consuls, Rabat; date of interview: 15.04.2014. 
MISCELLANEA GEOGRAPHICA - REGIONAL STUDIES ON DEVELOPMENT

Vol. 23 • No. 2 - 2019 • pp. 92-98 • ISSN: 2084-6118 • DOI: 10.2478/mgrsd-2019-0002

Table 1. Development phases of Moroccan souks under the influence of tourism

\begin{tabular}{|c|c|c|c|}
\hline \multicolumn{2}{|r|}{ Phase } & \multicolumn{2}{|r|}{ Type of transformation } \\
\hline No. & Period & Name & Description \\
\hline 1 & 1912-1955 & sight sacralisation & $\begin{array}{l}\text { - the recognition of the architectural, historical, and aesthetic values of } \\
\text { the souks by the colonial authorities in the context of tourism promotion } \\
\text { (connecting tourism with the cultural heritage protection policy) } \\
\text { - souks become a tourist attraction } \\
\text { the transformation of marketplaces into places for occasional meetings } \\
\text { between wealthy foreign tourists and locals }\end{array}$ \\
\hline \multirow[t]{3}{*}{ II } & \multirow{3}{*}{$\begin{array}{c}\text { 1956-early } \\
\text { 1990s }\end{array}$} & bazardisation & $\begin{array}{l}\text { - craftsmanship loses its importance and the business activity profile } \\
\text { changes from trade and production to trade alone } \\
\text { the emergence of new commercial outlets in the areas of existing } \\
\text { marketplaces and in other places, caused by the development of mass } \\
\text { tourism } \\
\text { the trade function replaces the housing function in many parts of the } \\
\text { medinas (proliferation of bazaars in areas visited by tourists) } \\
\text { the formation of commercial relations between tourists and sellers }\end{array}$ \\
\hline & & spatial dispersion & $\begin{array}{l}\text { - the movement of production and repair workshops from the core of the } \\
\text { souks to the outskirts of the medinas, away from the tourist routes }\end{array}$ \\
\hline & & bastardisation & 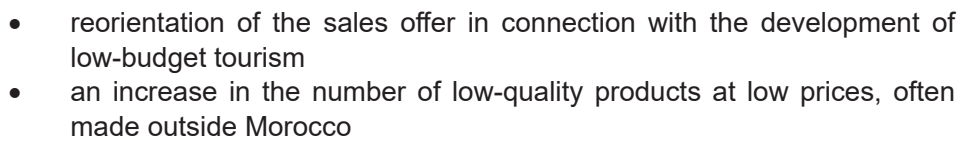 \\
\hline \multirow{3}{*}{ III } & \multirow{3}{*}{$\begin{array}{l}\text { Late 1990s- } \\
2014\end{array}$} & securitisation & $\begin{array}{l}\text { the establishment of the tourist police force, which increases the sense } \\
\text { of security among tourists and prevents conflicts between sellers and } \\
\text { tourists }\end{array}$ \\
\hline & & boutiquisation & $\begin{array}{l}\text { - the emergence of stores with exclusive clothing and accessories due to } \\
\text { the promotion of luxury tourism (designer shops with a reputation abroad } \\
\text { are a must on shopping routes for wealthy tourists) }\end{array}$ \\
\hline & & aestheticization & $\begin{array}{l}\text { - the paving and renovation of shop and workshop frontages, cleaning up } \\
\text { of stalls, installation of visual identification signs as part of tourism and } \\
\text { social projects } \\
\text { making traditional commercial and craft areas become, in the opinion of } \\
\text { many tourists, nicer and friendlier }\end{array}$ \\
\hline
\end{tabular}

Source: own elaboration based on fieldwork undertaken in 2014 and bibliographic query

was set up in 1996 in order to solve problems with beggars, unlicensed guides, and malicious acts carried out by indigenous people. In Rabat, the tourist police force was formed two years later, in 1998. Its mission - just as with Marrakesh - was to make tourists feel safe. With time, greater numbers tourists felt safer thanks to the tourist police (Leroux 2008). At the end of the twentieth century, the author of a guidebook claimed that it was possible to walk in (almost) complete safety in the souks in Marrakesh and in the areas directly adjacent to them (Gloaguen, Josse \& Duval 1999). These areas have become a place for evening meetings for tourists and residents, and a playground for children. One of the interviewees observed 'I can see armed gendarmes around. Yes, I do feel safe here. I was afraid before I arrived. I had heard about bomb attacks a few years before. ${ }^{10}$

In the 1990s, and also, especially during the first decade of the twenty-first century, there were many service points in Moroccan medinas which were strictly targeted at tourists. However, these were not just typical souvenir shops, they were boutiques with

${ }^{10} \mathrm{An}$ interview with a French tourist who came to Marrakesh with his girlfriend. Place of interview: Souk Semmarine, Marrakesh; date of interview: 15.12.2014. exclusive clothes or haberdashery, and perfumeries, which were a novelty. Most of these were established in the medina of Marrakesh, and also near the souks (Blaibel \& Sławoń 2011). The demand for these types of facilities came along with the promotion of the city as a luxurious tourist destination and, consequently, from an influx of jet-setting tourists from around the world (KurzacSouali 2011). Some of the shopping streets in the medina became subject to the process of 'boutiquisation. ${ }^{11}$ Rabat, however, was never a luxury tourist destination, rather, it was a short stop for less wealthy tourists touring Morocco and, therefore, much fewer of these exclusive stores were established there.

Since the end of the twentieth century, the aesthetics of public space in Moroccan medinas has improved, especially in Marrakech. The reason for this has been the rapid development of the accommodation base, especially in the central areas where the souks are located (Kałaska 2015). The owners of guest houses, mainly foreigners, set up street lighting systems to make it easier for tourists to reach their accommodation, and indirectly, to the

${ }^{11}$ The name 'boutiquisation' is used here on purpose. It was originally used to refer to the process affecting tribal elements in Thailand. (Cohen 2000). 
souks (Kurzac-Souali 2007b). In 2012, four tourist routes totalling 11 $\mathrm{km}$ in length were created. Two hundred and fourteen signs in three languages were placed on buildings, mainly in the form of signposts. Individual tourist traffic was channelled, and they were being provided with safe and easy access to the medina.

Furthermore, information signs were put up concerning sites of historical and commercial interest that would be encountered along the way, thanks to which the city's arts and crafts were promoted (Nachouane 2015). The signposting within the area of the souks, however, is invisible. This is how a confused tourist described the situation, 'We cannot reach the main square, we are almost constantly harassed by someone offering to show us the way. We will not be exploited. They are after our money, aren't they? Why are there no arrows at all?'12

\section{Discussion and conclusion}

The development of tourism has largely shaped the contemporary spatial structure of Moroccan cities. The medinas of Marrakesh and Rabat have been transformed to a great extent by tourism. They have changed as a result of tourist behaviour, as well as the activities of local authorities, and domestic and foreign entrepreneurs. This transformation has influenced the size, physiognomy and organization of the souks. It has also had an influence on the tradesmen and craftsmen working there. As a result, the medinas' commercial streets, especially those located on the routes connecting the most important monuments, have become the main tourist attractions of the cities. Due to this, characteristic relations have developed between tourists and sellers.

The impact of various mechanisms related to tourism has led to the emergence, or intensification, of the processes shaping the

\footnotetext{
${ }^{12} \mathrm{An}$ interview with a French student who came to Marrakesh with colleagues. Place of interview: Derb Dabachi, Marrakesh; date of interview: 14.12.2014.
}

Moroccan souks. Based on the information gathered, the authors identified three phases of souk development under the influence of tourism, identifying the dominant types of transformation that took place within them (Tab. 1.). These phases were separated by important historical events: between the first and second stages it was regaining independence, while between the second and third stages it was the establishment of the tourist police. The names of these types of processes were taken from the literature - their original meaning did not refer to the changes which took place in the commercial streets of the Moroccan medinas; however, they were used as an apt means of expressing the character of the changes observed in Morocco.

Certain types of transformations which have been identified as typical of a given phase of the souks' development under the influence of tourism may also occur in other phases. The table does not account for the hierarchy of the transformation types in terms of their impact on the souks.

The transformations occurring in Moroccan souks are complex and the attempt made to list them as they are in Table 1 above is probably incomplete. The above analysis is insufficient to claim that all of the types of changes discussed here can be identified for each of the souks in Morocco. The authors have concluded that in 2014, the souks in Marrakech were in an advanced third phase, which began in the 1990s. On the other hand, in the commercial streets of Rabat's medina, the signs of boutiquisation characteristic of this phase were visible to a much lesser extent at the time. Further research should verify whether the number of boutiques for wealthy tourists is growing there and monitor the processes of 'aestheticization' and securitisation.

\section{References}

Awad, JA 1989, Islamic souqs (bazaars) in the urban context: The souq of Nablus, M.A. thesis, Kansas State University, Manhattan.

Bacha, M 2008, 'La construction patrimoniale tunisienne à travers la législation et le journal officiel, 1881-2003: de la complexité des rapports entre le politique et le scientifique' ['Tunisian heritage building through legislation and the official journal, 1881-2003: the complexity of the relationship between politics and science'], L'année du Maghreb, vol. IV, pp. 99-122. Available from: <https://anneemaghreb.revues. org/433>. [1 March 2018].

Blaibel, B \& Sławoń, R 2011, Marrakesz [Marrakesh Guidebook], Biblioteka Gazety Wyborczej, Agora SA, Warsaw.

Bouzidi, MK 1996, Tourisme international et commerce des produits artisanaux à Marrakech (Maroc)' [International tourism and arts and crafts trade in Marrakesh (Morocco)]. $\mathrm{PhD}$ thesis, Université Panthéon-Sorbonne, Paris.

Carson, RT, Mitchell, RC \& Conaway, MB 2002, 'Economic benefits to foreigners visiting Morocco accruing from the rehabilitation of the Fes Medina' in Valuing Cultural Heritage, eds S Navrud \& RC Ready, Edward Elgar Publishing, Cheltenham/Northhampton, pp. 118-141.

Cauvin Verner, C 2005, Au désert : jeux de miroirs et acculturation. Anthropologie d'une situation touristique dans le Sud marocain [In the desert: games of mirrors and acculturation. Anthropology of a tourist situation in Southern Morocco], EHESS, Paris.

Cauvin Verner, C 2006, 'Les objets du tourisme, entre tradition et folklore' ['Tourism objects, between tradition and folklore'], Journal of africanistes, vol. 76(1), pp. 9-24.
Cohen, E 2000, The commercialized crafts of Thailand: Hill tribes and lowland villages, Curzon, Richmond

Daoudi, A 1994, L'organisation et le Règlementation du Tourisme au Maroc [Organization and Regulation of Tourism in Morocco], edition M.K. Bennani, Casablanca.

Dettmann, K 1969, 'Damaskus. Eine orientalische stadt zwischen tradition und moderne' ['Damascus. An oriental city between tradition and modernity'], Mitteilungen der Fränkische Geographische Gesellschaft, vol. 15/16, pp. 183312.

Ernst, I 2013, 'La médina de Marrakech dans le contexte de sa gentrification: un jeu virtuel et paradoxal' ['The medina of Marrakech in the context of its gentrification: a virtual and paradoxical game'] in Médinas Immuables? Gentrification et Changement dans les Villes Historiques Marocaines (19962010) [Immutable medinas? Gentrification and Change in Moroccan Historic Towns (1996-2010)], eds E Coslado, J McGuinness \& C Miller, Centre Jacques-Berque, Rabat, pp. $161-188$

Escher, A \& Schepers, M 2008, Revitalizing the Medina of Tunis as a National Symbol, Erdkunde, vol. 62, no. 2, pp. 129-143.

Escher, A \& Petermann, S 2014, 'Marrakech-Medina. Neocolonial paradise of lifestyle migrants?' in Contested Spatialities, Lifestyle Migration and Residential Tourism, eds M Janoschka \& H Hass, Routledge, New York, pp. 29-46.

Gloaguen, P, Josse, P \& Duval, M 1999, Maroc 1999/2000 [Morocco 1999/2000], Hachette, Paris.

Godin, L \& Le Bihan, G 2012, 'Moroccan medinas: Meknes and Azemmour' in The Medina: Restoration and Conservation of Historic Islamic Cities, ed M Balbo \& IB Tauris, London/New York, pp. 140-176. 
Hoffherr, R (ed.) 1936, 'Société d'Études économiques et statistiques', Bulletin Économique du Maroc, vol. 3, no. 13.

Jędrusik, M, Makowski, J \& Plit, F 2010, Geografia Turystyczna świata, Nowe Trendy, Regiony Turystyczne ['Tourism Geography of the World, New Trends, Tourism Regions'], Wydawnictwa Uniwersytetu Warszawskiego,Warsaw

Kałaska, M 2015, Changes in the distribution of quantitative features of guest houses in the Medina of Marrakesh, Miscellanea Geographica - Regional Studies on Development, vol. 19, no. 1, pp. 5-11.

Kurzac-Souali, AC 2007a, 'Adaptation économique et redéploiement culturel dans les médinas marocaines' ['Economic adaptation and cultural redeployment in the Moroccan medinas'] in L'enseignement supérieur dans la mondialisation libérale, ed S Mazzella, Institut de recherche sur le Maghreb contemporain, Tunis, pp. 307-327.

Kurzac-Souali, AC 2007b, 'Rumeurs et cohabitation en médina de Marrakech: l'étranger où on ne l'attendait pas' ['Rumors and cohabitation in the medina of Marrakesh: a foreigner where we did not expect him'], Hérodote, vol. 127, pp. 64-88.

Kurzac-Souali, AC 2011, 'Marrakech, insertion mondiale et dynamiques socio-spatiales locales' ['Marrakesh, global integration and local socio-spatial dynamics'], Méditerranées, vol. 116, pp. 123-132.

Lagdim Soussi, MB 1982, 'Le poids de l'artisanat dans la médina de Marrakech' in Présent et avenir des médinas: (de Marrakech à Alep), eds C Bousquet \& al, Institut de géographie, Tours, pp. 83-90.

Lagdim Soussi, MB 2002, 'La médina et les impacts du tourisme à Marrakech' ['The medina and the impacts of tourism in Marrakesh'], Revue de la FLSH, no. 16/17, pp. 83-122.

Leroux, S 2008, Le rapport à l'autre à travers le rapport à l'espace: l'example du tourisme français à Marrakech [The relation to the other through the relation to space: the example of French tourism in Marrakech]. PhD thesis, Université des Sciences et Technologie Lille 1, Université Cadi Ayyad, Lille/ Marrakesh.

Łęcka, I 2017, 'Bazar - centrum tradycyjnego krajobrazu kulturowego krajów islamu' ['Bazaar - the center of the traditional cultural landscape of islamic countries'], Prace Komisji Krajobrazu Kulturowego, vol. 38, pp. 9-22.

MacCannell, D 2013, The tourist: a new theory of the leisure class, University of California Pres, Berkeley.

Minca, C \& Borghi, R 2009, 'Morocco: Re-staging colonialism for the masses' in Cultures of Mass Tourism. Doing the Mediterranean in the Age of Banal Mobilities, eds P Obrador, M Pons \& M Crang, Ashgate, Farnham, pp. 21-52.

Nachouane, NE 2015, La Mise en Tourisme du Patrimoine Immatériel: Enjeux, Contextes et Logiques d'Acteurs. Le Cas de l'Artisanat dans la Médina de Marrakech à la Lumière des Experiences Espagnoles [Preparing the intangible heritage for tourism : Issues, contexts and logic of actors. The case of crafts in the Medina of Marrakech in the light of Spanish experiences]. PhD thesis, Université Cadi Ayyad/ Universidad de Murcia, Marrakesh/Murcia.

de Sardan, JPO 1995, 'La politique du terrain. Sur la production des données en anthropologie' ['The policy of fieldwork. On the production of data in anthropology'], Les terrains de l'enquête. no. 1, pp. 71-109.

Srinivas, MN, Shah, AM \& Ramaswamy, EA 1979, The fieldworker and the field: Problems and challenges in sociological investigation, Oxford University Press, New York.

Stafford, J 1996, Développement et tourisme au Maroc [Development and tourism in Morocco], Harmattan Inc., Montréal.
Théliol, M 2014, 'Aménagement et préservation de la médina de Rabat entre 1912 et 1956' ['Planning and preservation of the Rabat medina between 1912 and 1956'], Les Cahiers d'EMAM, vol. 22, pp. 47-70.

Troin, JF 1975, Les souks marocains. Marches ruraux et organisation de l'espace dans la moitié nord du Maroc [Moroccan souks. Rural markets and organization of space in the northern part of Morocco], EDISUD, Aix-en-Provence.

Widmer-Muünch, R 1990, Des Tourismus in Fes und Marrakech: Strukturen und Prozesse in bipolaren Urbanraumen des islamischen Orients [Tourism in Fes and Marrakech: Structures and Processes in Bipolar Urban Spaces of the Islamic Orient], Schwabe Verlag, Basel. 